\title{
The Role of School Leadership in Supporting Teacher Creativity to Improve Student Learning Outcomes in SMK Negeri 1 Al-Mubarkeya Ingin Jaya
}

\author{
Rahmi Isra \\ Akademi Maritim Aceh Darussalam, Indonesia \\ rahmi.isra92@gmail.com
}

\begin{abstract}
The research objectives are to determine and analyze the role of principal leadership in increasing teacher creativity at SMK Negeri 1 Al-Mubarkeya Ingin Jaya and to find out and analyze teacher creativity in improving student learning outcomes at SMK Negeri 1 Al-Mubarkeya Ingin Jaya. This study used a qualitative approach using purposive sampling technique to determine informants and data collection techniques were carried out through observation, interviews and focus group discussions (FGD). The role of principal as education leader in increasing the creativity of teachers in State Vocational High School I AlMubarkeya Ingin Jaya, Aceh Besar District, still has several shortcomings. This can be seen from the indicators that the principal as an educator is still not maximal in guiding teachers to prepare learning tools. The principal as a supervisor is still not able to prepare a supervision program properly, because he does not do classification of problems and check the correctness of the problem. The implementation of supervision is still constrained by curriculum differences. The principal as a leader also still has shortcomings so that it has implications for the level of creativity guru in improving student learning outcomes. Teacher There are still those who have difficulty in formulating and classifying specific instructional goals to develop students' attitudes, knowledge, and skills.
\end{abstract}

Keywords

satisfaction; public service; licensing

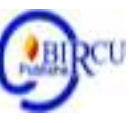

\section{Introduction}

The importance of the principal's role in leading an educational institution to shape teacher creativity, through this role as an educator, supervisor and leader. The role of the principal as an educator includes the ability to guide teachers, the ability to guide students, the ability to learn to keep up with the development of science and technology and the ability to provide good teaching examples. The role of the principal as a supervisor includes the ability to compile, program supervision, the ability to carry out the supervision program and the ability to process the results of supervision. The principal as a leader needs to have a strong personality, understand the condition of students, have the ability to make decisions, and have the ability to communicate.

This is as the opinion expressed by Wahjosumijo (2013) states that the principal is successful if they understand "the existence of the school as a complex and unique organization, and are able to carry out the role of the principal as someone who is given the responsibility of leading the school". Furthermore, the responsibilities of school principals are explained in more detail by Mulyasa (2012) that, "Principals at least have 
Konfrontasi Journal: Culture, Economy and Social Changes, 7 (4) December 2020, 293-302

ISSN: 1410-881X (Print), 2716-2095 (Online)

Rahmi Isra: The Role of School Leadership in Supporting Teacher Creativity to Improve Student Learning Outcomes in SMK Negeri 1 Al-Mubarkeya Ingin Jaya

DOI: https://doi.org/10.33258/konfrontasi2.v7i4.127

http://www.konfrontasi.net/index.php/konfrontasi2

responsibilities as Educators, Managers, Administrators, Supervisors, Leaders, Innovators and Motivators (EMASLIM)".

Through the leadership role of the principal, it is expected to be able to produce creative teachers, including in choosing teaching methods that are able to achieve learning objectives and choosing methods that are in accordance with the characteristics of students. Then, through the role of the principal, it can also give birth to the creativity of teachers in creating media or props in order to attract students' interest. The creativity of a teacher is useful for increasing student interest in subjects and teacher creativity will stimulate student creativity. The application of teacher creativity products, for example, is in the form of instruments that are able to invite students to learn in the real world through visualization in order to be able to motivate students and reduce student boredom and increase their interest in lessons.

The leadership role of the principal in giving birth to teacher creativity, especially in formulating various learning objectives or instructional objectives, both specific instructional according to the 2013 curriculum, being able to classify specific instructional goals in developing student attitudes, knowledge and skills, and formulating lesson plans that develop attitudes, knowledge and student skills. Teacher creativity in choosing companion books for students, such as learning textbooks that support learning material and selecting learning textbooks according to the applicable curriculum.

Leadership can be defined as a process of directing and giving influence to the activities of a group of members who are related to their duties (Stoner, 1992: 114). According to Gorton et al., Leadership is a characteristic of leaders in influencing subordinates to achieve organizational goals. The success of leadership is partly determined by the ability of leaders to develop their organizational culture. (Arif, 2019).

Teacher creativity is also useful in transferring more complete information, the results of innovation in the form of educational aids will provide complete data or information, this can be seen in the active senses of students, both the senses of sight, hearing and smell, through media or props so that students seem to encounter situations that are like the original. Teacher creativity is also useful in stimulating students to think more scientifically in observing community phenomena or natural phenomena that are the object of study in learning.

The description previously explained by the previous researcher is in line with the regulation of the Minister of National Education Number 28 of 2010 concerning the assignment of teachers as principals of schools / madrasas, which defines the principal as a teacher who is given additional duties to lead kindergarten / raudhotul athfal (TK / RA), kindergarten special children (TKLB), primary schools / madrasah ibtidaiyah (SD / MI), special primary schools (SDLB), junior high schools / madrasah tsanawiyah (SMP / MTs), special junior high schools (SMPLB), secondary schools above / madrasah aliyah (SMA / MA), vocational high school / vocational high school (SMK / MAK), or special high school (SMALB) which is not an international standard school (SBI) or which has not been developed into an international standard school (SBI). 


\section{Review of Literatures}

\subsection{Role Theory}

Role theory is known as the role of theory, this is a theory that analyzes the tasks that must be carried out by people or institutions that have formal or informal positions. In the Indonesian dictionary, there are two terms that appear, namely role and role. A role is a set of levels that a person in society is expected to have. While the role is part of the main task that must be carried out. Selly in Salim (2014) defines the role as "The task carried out by the leader to improve the quality of the institution he dreams of through increasing the capacity of staff or people who carry out organizational activities".

From the definition above, the role is constructed as a function or position of the subject in an organization and in relation to its output. Mukti in Salim (2014) states that role theory is "a theory that studies that someone will work and behave according to their status and role". Community behavior is a response or reaction that is manifested in movement (attitude), but also body movements or speech in society. So role theory is a theory that studies and analyzes the role of both school and community institutions in solving, resolving and ending problems that arise in everyday life.

Role theory put forward by Robert in Salim (2014) that "Social interaction in the terminology of the actors who have links is in accordance with what is determined by culture". In accordance with this theory, role expectations are shared understandings that guide us to behave in our daily lives. According to this theory, someone who has a certain role, for example the principal, is expected to behave in accordance with that role. Why does someone treat another, because he's a doctor. So because his status is a doctor, he must treat patients who come to him and behavior is determined by his social role. Glen Elder in Salim (2014), expanded the use of role theory by using an approach called "live caurse" which means: Each institution has the expectation of each member to have certain behaviors in accordance with the age categories that apply in the organization. For example, in a school organization, there is a school principal as a leader, a teacher as an implementer of activities and a student as a person who is taught in accordance with the applicable provisions of the institution.

\subsection{Leadership Theory}

A leader is essentially someone who has the ability to influence the behavior of others in his work by using power. Power is the ability to direct and influence subordinates in relation to the tasks that must be carried out.According to Purwanto (2012) "The leadership of the principal is a leader at the level of school organization institutions that will determine how the overall performance of the organization, while the teacher is a leader at the level of learning techniques that will determine the success of the learning process in order to produce quality learning / education output". Meanwhile, according to Purwanto (2012) "The teacher is a leader in the level of learning techniques that will determine the success of the learning process in order to produce quality learning / educational output".

According to Stoner (2012), the greater the number of sources of power available to leadership, the greater the potential for effective leadership. This type of leader varies, there is a formal leader, which occurs because the leader relies on formal authority. There are also informal leaders, which occur because leaders without formal authority succeed in influencing the behavior of others. As stated above, power comes from rewards, coercion, expertise, references, law, charisma / personal strength. Based on that, subordinates or people accept or do not accept everything that must be done. 
The leadership of the principal as a leader in the school certainly has a very important function and role in improving the quality of the school. Schools will have good quality if the performance of the people in the school runs optimally. In order to optimize the performance of the people in the school, the principal must understand the situation and conditions in the school and be able to act fairly in carrying out his duties. The leadership of the principal is at the same time a manager in the school because a leader also carries out management functions in charge of planning, organizing, controlling, and leading. The description above is in accordance with Tiong's opinion in Usman (2012) which states that an effective school principal has the following characteristics:

a. Fair and firm in making decisions;

b. Divide assignments fairly to the teacher;

c. Value staff participation;

d. Understanding the teacher's feelings;

e. Have a vision and seek to make changes;

f. Skilled and orderly;

g. Capable and efficient;

h. Dedicated and diligent;

i. Sincere and confident.

The opinion related to the effectiveness of school principal leadership according to Usman (2012) has the characteristics of effective leadership of school principals in the 21st century are as follows:

a. Leadership that is honest, defends the truth, and has core values;

b. Leadership who is willing and able to listen to the voices of teachers, education staff, students, parents, and school committees;

c. Leadership that creates a realistic vision of belonging;

d. Reliable leadership based on data;

e. Leadership that starts with introspection and reflection on oneself first;

f. Leadership that empowers itself and its staff and is willing to share information;

g. Leadership that involves all human resources in schools, overcomes obstacles to change both personally and organizationally.

The principal is considered a person who has high expectations for all school members. The principal knows various school developments. This is in accordance with the opinion of Mulyasa (2012) that "the principal is the driving force, determines the direction of school policy, which will determine how the goals of school and education in general are realized". Purwanto (2012) states that "Among educational leaders of various types and levels, the principal is a very important educational leader". It is said to be very important because it is closer and directly related to the implementation of education programs in each school.

\subsection{Educational Theory}

Education is a conscious effort to create an atmosphere of learning and the learning process so that students actively develop their potential to have religious spiritual strength, self-control, personality, intelligence, noble character and skills needed by themselves, society and country. Education has a very important role in the process of improving the quality of human resources, as stated in the Constitution (UUD) of the Republic of Indonesia Number 20 of 2003 concerning the national education system, namely: National education functions to develop capabilities and shape the character and civilization of a nation with dignity in in order to educate the nation's life, aiming at developing the potential of students so that they become human beings who believe in God Almighty, are healthy, 
knowledgeable, creative, independent and become democratic and responsible citizens, humans have the same right to get education.

Purwanto (2012). Stating: almost everyone has experienced education, but not everyone understands the meaning of education, there are two terms that can lead to understanding the nature of education, namely the words paedagogie and paedagogiek. Paedagogie means education. Meanwhile, pedagogiek means education. Ramayulis (2012) states that: "Education starts with the family of children who are not yet independent, then it is expanded to neighboring or surrounding communities, formal schooling institutions and others where children start from small groups to groups / classes to educate micro and become a substitute for parents ". Education in the next session presented as a symptom of human behavior and efforts to meet the basic needs of survival.

Etymologically, the word pedagogie comes from Greek, namely paedagogia which means association with children. Paidagogos are pests or people whose jobs are to deliver and take slaves to and from school. The word paida refers to children, which is why some people tend to distinguish between pedagogy (teaching children) and andragogy (teaching adults). Education is also a process of digging human beings towards the peak of optimizing their cognitive, affective, and psychological potential. According to Sudarwan (2012) education is "the process of guiding, training and guiding humans to avoid or get out of ignorance".

Symptoms of education arise when a group of individuals wants to fulfill the knowledge, value of justice, prosperity, and skills so that they feel from conditions of deprivation such as poverty, disease, or lack of ability to interact. The real purpose of education is awareness of self-knoing and self-releaation then inquiry and reasoning and logic. So it is clear that the purpose of education is to provide awareness of what he knows, then this knowledge must be realized by himself and then conduct research and know the causal relationship, namely the reasons and the flow of thought".

The principal in improving the quality of education has been involved since the preparation of the syllabus as a learning plan for a particular subject and / or group of subjects / themes which include competency standards, basic competencies, subject matter / learning, learning activities, indicators, assessments, time allocation, and resources. / materials / learning tools. According to Mulyasa (2012) the syllabus is "a lesson plan in a group of subjects with a specific theme, which includes competency standards, basic competencies, learning materials, indicators, assessments, time allocation, and learning resources developed by each educational unit".

Then the principal in improving the quality of education is also involved in the preparation of an annual program based on the results of the analysis of predetermined time allocations and the results of the mapping of basic competencies per unit of subject. This shows that the teacher must prepare the tools that must be implemented in planning the program. In accordance with the theory put forward by Majid (2015) that "the tools that must be prepared in learning planning include: understanding the curriculum, mastering teaching materials, compiling teaching programs, implementing teaching programs, and assessing teaching programs".

The annual program is translated into a semester program. Semester program is a program that contains outlines about things to be implemented and achieved in one semester. This semester program is a translation of the annual program. In general, the components of this semester program are: identification (educational unit, subject, semester, academic year), month, competency standard and main material to be delivered, planned time and information. Semester is a unit of time used for implementing educational programs. Activities carried out in that semester are face-to-face activities, practicum, field work, mid- 
semester, semester exams and various other activities that are given success assessments. The preparation of the semester program is based on the results of the analysis of pre-determined time allocations and the results of the mapping of basic competencies per unit of subject This shows that the teacher must prepare the tools that must be implemented in planning the program. In accordance with the theory put forward by Majid (2015) that "the tools that must be prepared in learning planning include: understanding the curriculum, mastering teaching materials, compiling teaching programs, implementing teaching programs, and assessing teaching programs".

The Learning Implementation Plan (RPP) is essentially a short-term plan to estimate or project what will be done in learning. Thus, the lesson plan is an attempt to estimate the actions to be taken in learning activities. The lesson plan needs to be developed to coordinate the learning components, namely: basic competition, standard materials, learning outcome indicators, and assessment. Basic competition serves to develop the potential of students: standard material serves to give meaning to basic competition; learning outcome indicators function to show the success of forming student competencies; meanwhile, the function of assessment measures the formation of competencies, and determines the actions that must be taken if standard competencies have not been established or have not been achieved.

The syllabus and lesson plan show that the teacher makes a teaching syllabus which is followed by making teaching plans before starting teaching activities. This is in accordance with the theory put forward by Suherman (2013) that "a learning plan is a series of strategies that are developed in an advanced, sustainable manner, and are used to help students achieve specific learning goals that have been set". In making lesson plans, guidelines for making teaching plans are needed in the form of supporting references to the subject matter to be delivered and later a question bank is also created.

The one day one verse program is developed by each school with the aim of presenting religious values to each student's soul, so that the religious experience at school will shape the mental and religious attitudes of each student, which in educational theory is known as the internalization of religious values. in the life of students. This is in accordance with the theory put forward by Azizah (2014) "Establishing a religious atmosphere in the school environment in the form of mutual respect between students and teachers. Establishing a calm atmosphere / climate in daily school activities.

Then morning exercise is not only assumed as a mere physical activity. To improve the quality of schools, the role of supervision is very decisive as a study material for improving human resources. Following are the findings that the authors obtained from the informants, namely: The principal made a supervision planning program. In its implementation, classroom supervision is assisted by 2 vice principals. In addition, supervision is carried out for the assessment of teacher report cards and planning for future improvements in Human Resources (HR).According to Mulyasa, (2013) "one of the duties of the principal is as a supervisor, which is to supervise the work performed by educational personnel". One of the things that encourages improvement in teacher professionalism is by participating in upgrading / training. According to Notoatmodjo (2013) "education and training are efforts to develop human resources, especially to develop intellectual abilities and human personality". Professional teachers at least have the following characteristics: (1) committed to the student learning process; (2) deeply mastering the subject matter and how to teach it; (3) able to think systematically about what they do and learn from their experiences;

Principals as the driving force for improving teacher performance are required to have a broad vision, mission and insight as well as adequate professional skills in planning, organizing, implementing and supervising education delivery. In addition, school principals 
are required to have the ability to build harmonious cooperation with various parties related to educational programs in schools. The ability of the principal will certainly influence the performance of teachers in carrying out their duties. One of the principal performance indicators is assessed based on the implementation of duties and roles. And one of the roles of the principal is as an administrator and supervisor in an effort to improve teacher performance, the role of the principal is very important.

The principal has the role of administrator and supervisor, basically providing professional services to improve the quality of education through improving teacher performance. The conditions for the implementation of coaching by the principal are activities carried out to oversee the implementation of school administration, the routine duties of teachers, order, discipline and school success. The activities of coaching school principals as above will certainly have an effect on improving teacher performance.

The success of schools is inseparable from the duties and responsibilities as well as the role of the principal. In improving teacher performance, the role of the principal is very large, evidence that this role is very large is where the absence of the principal makes teaching and learning activities less focused and controlled. Even if it runs, the teaching and learning activities just run, remembering that every teacher who will deliver the subject matter first makes a daily teaching program to be researched and approved by the principal.

The role of the principal as administrator has two main duties. First, controlling the organizational structure, namely controlling how to report, with whom the task must be done and with whom to interact in carrying out the task. Second, implementing substance administration which includes curriculum administration, student affairs, personnel, finance, public relations facilities, and general administration. The role of the principal as a supervisor, is obliged to provide guidance or guidance to teachers and other education and administrative personnel. However, before providing coaching and guidance to others, the principal must foster himself, as a supervisor he must research, find and determine which conditions are needed for the progress of his school.

\section{Research Methods}

The method used in this research is qualitative, referring to the opinions expressed Moleong (2014) qualitative approach is "Research which intends to understand the phenomena experienced by research subjects such as behavior, perception, motivation, actions, etc. Holistically and in the form of words and language". WhileSugiyono (2012) states that qualitative research is "a research method used to examine the condition of a natural object, where the researcher is the key instrument". Meanwhile, the determination of informants in this study was carried out through purposive sampling technique. According to Sugiyono (2012) purposive sampling is "a sampling technique with certain considerations". By using purposive sampling, it is expected that the sample criteria obtained are really in accordance with the research conducted and are able to explain the actual situation of the object under study.

The stages in the data analysis above are inseparable parts, so that they are interconnected between one stage and another. The analysis was carried out continuously from the beginning to the end of the study, to find out how the authority of school administration was and how posyandu was organized. In accordance with the type of research above, the researcher uses an interactive model from Miles and Huberman in Sugiyono, 2012) to analyze the data from the research activities in qualitative data analysis carried out interactively and continuously until it is complete, so that the data is saturated. The interactive model is as follows: 


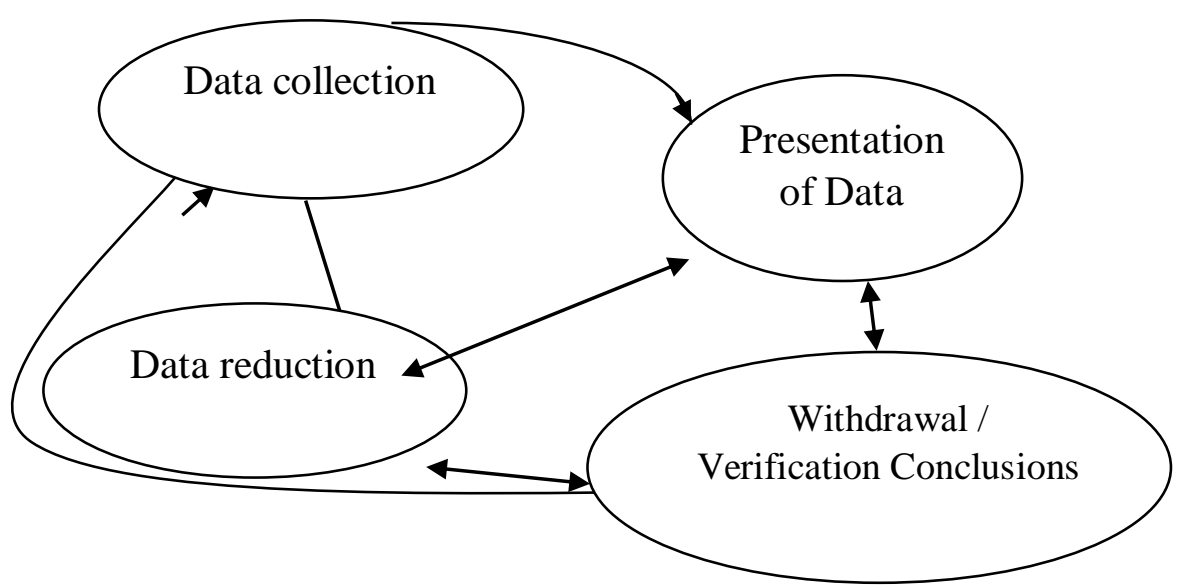

Figure 1. Components of Interactive Analysis

Source: Miles and Huberman in Sugiyono (2012).

\section{Discussion}

SMK Negeri 1 Al-Mubarkeya Ingin Jaya is located in the Kuwaiti Housing Complex of Kayee Lee Village, Jalan Rider Dormitory, Wish Jaya District, Aceh Besar District $1.3 \mathrm{Km}$ from the Lambaro roundabout, this school building was handed over from the Kuwait Red Crescent to the Aceh Besar Regional Government on the 22nd August 2013 with its establishment number 254 of 2014 and began operating at the time of the first new student admission in May 2014 under the name SMK Negeri 1 Al-Mubarkeya Ingin Jaya. Based on the Government Regulation of the Republic of Indonesia Number 32 of 2013 concerning National Education Standards states that the learning process in educational units is held in an interactive, inspiring, fun, challenging, and motivates students to actively participate, and provides sufficient space for initiative, creativity, and independence according to the talents, interests, and physical and psychological development of students, the principal of SMK Negeri 1 Al-Mubarkeya has a strong personality and is able to inspire teachers, employees and students. This study only discusses the principal as an educator, supervisor and leader. This is because this role is directly related to the teaching activities of the teacher in schools.

The principal is very supportive of teachers who want to innovate in making media or visual aids. The school principal even tries to fulfill the facilities, infrastructure, provide advice / guidance and help with problems faced by teachers. Although there are still many obstacles such as power outages, incomplete laboratory equipment, students in certain majors are required to have laptop and basic skills

The role of the principal as an education leader in increasing the creativity of teachers at SMK Negeri I Al-Mubarkeya Ingin Jaya, Aceh Besar District, still has several shortcomings including the inadequate ability of the principal as an educator. Insufficient supervisory ability in compiling and implementing it. His role as a leader is also still lacking in his ability to understand students is still weak and the decisions taken regarding students are still inaccurate.

Teachers at SMK Negeri 1 Al-Mubarkeya are quite creative in using media and visual aids. Purwanto (2012) states that teachers are always endeavored to be creative in creating learning media. It is endeavored for a teacher to be able to create his own teaching aids that are more attractive than the props purchased from the store. Some teachers of SMK Negeri 1 Al-Mubarkeya who use media or props that they design themselves based on the material to be taught. 
There are still some teachers at SMK Negeri I Al-Mubarkeya who have difficulties in formulating and classifying specific instructional goals to develop students' attitudes, knowledge, skills. There are still teachers at SMK Negeri I Al-Mubarkeya who formulate lesson plans monotonously and less creatively so that they cannot develop student attitudes, knowledge, skills with the help of available props and technology. So it can be concluded that the teachers at SMK Negeri I Al-Mubarkeya Ingin Jaya, Aceh Besar District still need to make improvements in their work to become more creative teachers.

\section{Conclusion}

The role of the principal as an education leader in increasing teacher creativity in State Vocational High School I Al-Mubarkeya Ingin Jaya, Aceh Besar District, still has several shortcomings. This can be seen from:

a. The principal as an educator still has some drawbacks, namely, he has not been maximal in guiding teachers to prepare learning tools, this is due to differences in the curriculum and the activities of the principal. Training for employees is also lacking. The principal contributes less in guiding students and more is left to the BK teachers and teachers.

b. The principal as a supervisor is still not able to prepare a supervision program properly, because he does not do classification of problems and check the correctness of the problem. The implementation of supervision is still constrained by curriculum differences.

c. The principal as a leader still has a deficiency in understanding the condition of students because information is only obtained from the teacher and lack of communication with the average student results in the condition of students sometimes not being described as a whole so that their ability to understand students is still weak and decisions made regarding students are still less precise.

Teacher creativity in improving student learning outcomes still lacks enough creative in the teaching and learning process. However, there are different perceptions in the formulation of special instructions, the creativity of the lesson plans is hindered limited availability of props for supporting facilities, this can be seen by:

a. Teacher in There are still those who have difficulty in formulating and classifying specific instructional goals to develop students' attitudes, knowledge, and skills. There is still a Guruin State Vocational High School I Al-Mubarkeya which formulates RPP monotone and is less creative so that it cannot develop students' attitudes, knowledge, skills with the help of available props and technology. Teacher still need to make improvements to work to become a more creative teacher.

b. Teacher I am still confused about teaching with the 2013 curriculum book. So I often teach using material from other companion books. The 2013 curriculum book is only a material guide.

c. There are still teachers who cannot afford it choose a method learning so that it is monotonous and often uses the same method as a result the learning objectives are not achieved. Subject teachers must provide special guidance to students who have difficulty understanding lessons and there are still teachers who use monotonous methods.

The author suggests to the principal of SMK Negeri 1 Al-Mubarkeya to be able to continue to increase support for the development of teacher creativity and continue to encourage productive teachers to be more creative in teaching and creating Learning Innovations, For Teachers to be even more active in developing creativity and applying methods new methods in accordance with the times, such as optimizing the use of technology in the learning process to attract students' interest and facilitate the learning process. 
The author also hopes that the good program of SMK Negeri 1 Al-Mubarkeya can be a good example for other schools. Such programs include the provision of extracurricular English study clubs, the division of classes in the morning and afternoon to deal with class shortages, democratic leadership methods that are practiced properly and the principal's excellent response to teachers, employees and students. This research is also expected to be an input for other researchers who want to carry out similar research, although there are still limitations in this study.

\section{References}

Arif, S. (2019). Influence of Leadership, Organizational Culture, Work Motivation, and Job Satisfaction of Performance Principles of Senior High School in Medan City. Budapest International Research and Critics Institute-Journal (BIRCI-Journal). P. 239-254

Azizah. (2014). Evaluation Method. Yogyakarta: Graha Science.

Bungin, Burhan. (2011). Revised Edition. Qualitative Research Data Analysis. Philosophical and Methodological Understanding of the Direction of Mastery of the Application Model. Jakarta: Raja Grafindo Persada.

James Owen. (2013). The Hand Book of Education Management Theory and Practice of Management of Primary Schools / Madrasahs in Indonesia. Yogyakarta: Prenada Media Group.

Majid, Abdul. (2015). Learning strategies. Bandung: PT. Rosdakarya youth.

Moleong, Lexy J. (2014). Qualitative Research Methods. Bandung: Youth Rosdakarya.

Mulyasa, E. (2012). Become a Professional School Principal. Bandung: PT Remaja Rosdakarya.

Notoatmojo. (2013). Health Promotion and Behavioral Sciences. Jakarta: Rineka Cipta.

Regulation of the Minister of National Education. (2010). Assignment of Teachers as Principals of Schools / Madrasahs. Jakarta: Regulation of the Minister of National Education Number 28 of 2010.

Republic of Indonesia Government Regulation. (2017). Teacher. Jakarta: Government Regulation of the Republic of Indonesia Number 19 of 2017.

Purwanto, N. (2012). Education Administration and Supervision. Bandung: Rosdakarya.

Ramayulis. (2012). Science Education. Jakarta: Kalam Mulia.

Salim and Nurbani. ICE. (2014). Application of Legal Theory in Dissertation and Thesis Research. Jakarta: PT. Raja Grafindo Persada.

Stoner. J. A F. \& Freeman, RE (2012). Management: Structure and Process. Interpretation of Languages: Nunuk, Ardiani. Jakarta: PT Prenhallindo.

Sudarwan. (2012). Lifelong Education. Jakarta: Depdikbud.

Sugiyono. (2012). Understanding Qualitative Research. Bandung: Alfabeta

Suherman. (2013). Learning strategies. Bandung: PT. Rosdakarya youth.

Suryana. (2011). Entrepreneurship. Jakarta: Four Salemba

Law Number 20 of 2010 about education.

Law No. 14 of 2005 on teachers and lecturers.

Usman. (2012). Character Leadership as a Character Education model. Journal of Character Education.

Wahjosumidjo. (2013). Leadership Principal theoretical review and problems. Jakarta: PT. Raja Grafindo Persada.

Wahyudi. (2012). Leadership of Principals in Learning Organizations (Learning Organization). Bandung: Alfabeta. 